\title{
Landslides-flows on rock dumps of coal mining enterprises
}

\author{
Svetlana Rybalchenko ${ }^{1, *}$, Konstantin Verhovov $^{2}$, and Sergei Kudriavtcev ${ }^{3}$ \\ ${ }^{1}$ Far East Geological Institute of Far Eastern Branch Russian Academy of Science, Sakhalin \\ Department, Gorkogo str., 25, Yuzhno-Sakhalinsk, 693000, Russia \\ ${ }^{2}$ Sports and tourist complex "Mountain air", Gornyj vozduh str., letter B, Yuzhno-Sakhalinsk, \\ 693000, Russia \\ ${ }^{3}$ Far Eastern State Transport University, Serysheva, 47, Khabarovsk, 680021, Russia
}

\begin{abstract}
The paper considers one of the most dangerous slope exogenous processes formed on the rock dumps of coal mining enterprises - landslidesflows. The mechanism of occurrence, movement and accumulation of landslides-flows, mechanisms of negative impact on objects and territories is described. The factors of activation of landslides-flows on rock dumps of coal mining enterprises (anthropogenic, meteorological, hydrological, hydrogeological and geological factors).
\end{abstract}

\section{Introduction}

Production processes of mining enterprises are associated with the movement of significant volumes of rocks: their loosening, mining, sorting, transportation, storage and further processing (if necessary). Anthropogenic impact is exposed to significant areas, the areas of which can reach several thousand square kilometers, and the volume of storage is tens and hundreds of millions of cubic meters. On these territories there is a violation of natural landscapes and the formation of special man-made landscapes, represented by various elements of the relief of anthropogenic origin: quarries, rock dumps, waste piles, tailings, man-made deserts, etc.

Technogenic landscapes are characterized by a significant energy of the relief created artificially and in contrast to the relief of natural landscapes that have not undergone a longterm gravitational transformation, as well as a significant increase in surface runoff, due to the lack of transpiration and the weakening of reduction within the drainage basins caused by the reduction of vegetation and soil cover. Technogenic soils involved in the formation of these landscapes are characterized by a decrease in the total number of rigid structural bonds and an increased content of fine dust particles in connection with the use, during mining and overburden removal drilling and blasting and mechanical methods of disintegration of rocks. These circumstances cause the active involvement of man-made soils in dangerous slope exogenous processes of gravitational, water-gravity and fluvial nature (landslides, falls, debris flows, etc.). The greatest danger is posed by external (which are beyond the limits of

\footnotetext{
*Corresponding author: rybalchenko_sv@mail.ru
} 
mine workings) rock dumps and tailings, with a significant reserve of potential energy due to their location, layout, elevations and a significant amount of mass placed in them.

It is especially worth noting the rock dumps of coal mining enterprises, which in addition to large volumes of storage is characterized by a long period of their operation due to the long time of development of the field.

Reclamation of mine workings and rock dumps during the development of the field is not possible. In case of accidents, as well as manifestations of dangerous exogenous processes on the rock dumps of coal mining enterprises, the consequences can be catastrophic.

\section{Catastrophes in the rock dumps of coal-mining enterprises}

Cases of formation of dangerous slope exogenous processes on the rock dumps of coal mining enterprises are quite common. The most famous of them is the "tragedy in Aberfan" occurred on October 21, 1966 in the village of Aberfan (Wales, Great Britain).

After many days of incessant heavy rains on the mine spoil dump Martin vail, located on the slope of the mountain range Minidom Martyr went largest landslide-flow volume of 150 thousand $\mathrm{m}^{3}$. Watered man-made soils of the rock dump, stored in unfavorable hydrogeological conditions on this site for more than 50 years, came in motion and at a speed of $30 \mathrm{~km} / \mathrm{h}$ rushed to the foot of the slope, where the village of Aberfan was located. On the way of the landslide-flow movement on the gentle parts of the slope there was its partial deposition and speed reduction up to $15 \mathrm{~km} / \mathrm{h}$. Landslide masses, reaching the streets of Aberfan, buried 20 houses and the building of the primary school. Despite the fact that the rescue operation began immediately after the landslide was stopped and significant resources were attracted to it, only a few people managed to extract alive from under the rubble in the first hour of the operation. The victims of the landslide-flow were 144 people, including 116 children aged 7 to 10 years. "The tragedy in Aberfahn" caused a significant change in UK legislation in the field of subsoil use, which previously did not regulate the activities of coal mining enterprises on external rock dumps (Fig. 1a) [2].

It should be noted that recently in the territory of the Russian Federation in connection with a significant increase in the volume of coal production (the production volume is over 400 million tons per year), there have also noted many cases of dangerous slope exogenous processes on rock dumps.

On April 1, 2015, a large landslide-a flow of 27.5 million $\mathrm{m}^{3}$ descended from the rock dump of the coal mine "Zarechny" (Kemerovo region, Russia). As a result of collapse of a dump of overburden breeds support of a power line were damaged, objects in the territory of the enterprise are de-energized, under blockages with a total area of 22 hectares there was a two-track railway branch and the highway, a set of units of a rolling stock, warehouses and structures, and also the Kyrgyz riverbed is poured [1].

May 14, 2018 in the village of Gornozavodsk (Sakhalin region, Russia) landslide-flow of 500 thousand $\mathrm{m}^{3}$, formed on the rock dump of the coal mining enterprise, breaking several hundred meters through the valley of the stream, damaged the house and farm buildings in the territory located near the farm (Fig. 1 b). The landslide created a threat of the collapse of the spawning river Lopatinka, through which water withdrawal for household and drinking water supply is also carried out. Gornozavodsk: more than 4,000 people were threatened by the ecological and humanitarian disaster.

The described cases of formation of landslides-flows on rock dumps of coal-mining enterprises visually demonstrate negative mechanisms of impact and damaging factors of this phenomenon. Having significant volumes (up to several million $\mathrm{m}^{3}$ ), landslides-flows have a large area of damage and pose a serious threat to linear facilities, including engineering networks and transport highways, water objects, agricultural land and forest fund lands, economic activities, residential building, rolling stock, farm animals and the population. 


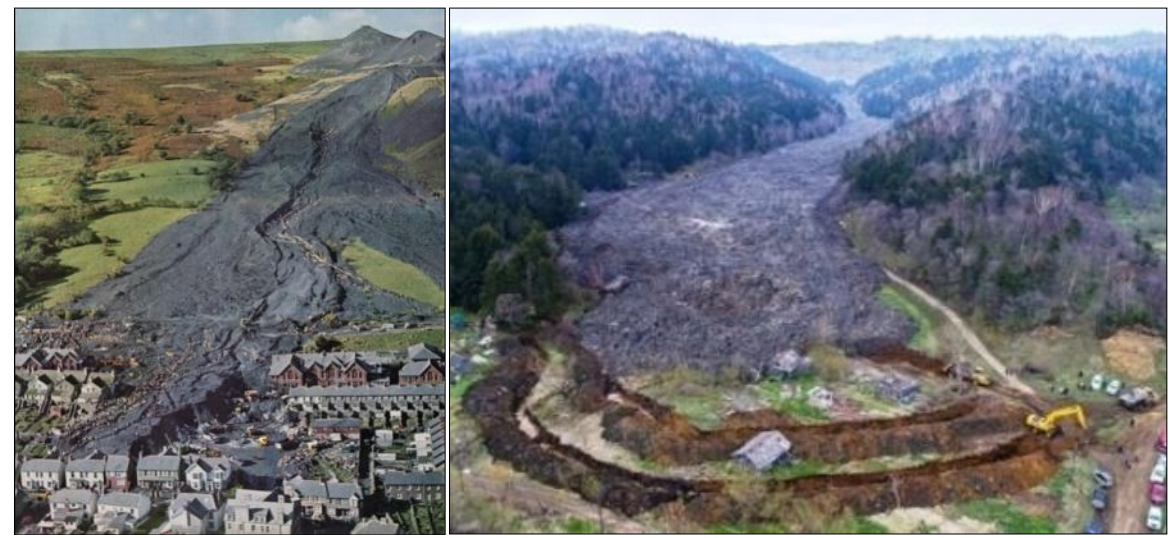

Fig. 1. a) Landslide-flow in Aberfane. October 1966. Photo: https://en.wikipedia.org/wiki/Aberfan_disaster b) Landslide-flow in with. Gornozavodsk. May 2018. Photo: http: //sovsakh.ru/opolzen-v-gornozavodske.

The movement of landslides-flows occurs at low speeds (from a few meters per hour to 2-4 m/s), despite this, people (especially people with limited mobility) who are in rooms or other cramped conditions and are not able to leave the landslide transit zone in a timely manner, can be under the rubble. At sufficiently high densities (up to $2.3 \mathrm{t} / \mathrm{m}^{3}$ ) landslide masses have high plasticity, which allows them to easily penetrate into the premises and buildings. The high front of the landslide-flow, the plasticity and the nature of the motion of landslide masses contribute to the fact that various objects in the path of the landslide are buried under the rubble. When a person hits a landslide stream, the chances of survival are extremely small. Cases of formation of large landslides-flows on the rock dumps of coal mining enterprises are often qualified as an emergency of regional scale.

\section{The mechanism of the development of landslide-flows in rock dumps}

External rock dumps of coal-mining enterprises are composed of man-made soils with a low coefficient of compaction and a high content of coal dust particles, which, in case of storage with violation of the norms for ensuring stability and water disposal, leads to the development of dangerous slope exogenous processes for which man-made soil of the dumps is a source of solid nutrition. Overmoistening of the coal rock in dumps is associated with the danger of the development of landslides and landslides-flows, the cause of which is due to the formation of man-made soils in the arrays of water-carbon suspensions.

Coal dust particles, having a finely dispersed composition (from $300 \mu \mathrm{m}$ to $50 \mu \mathrm{m}$ ) and a negative charge, exhibit pronounced colloidal properties, actively bind water and form stable water-coal suspensions. Such suspensions are characterized by saturated consistency (up to $70 \%$ ) and pseudoplasticity - the property of reducing viscosity with increasing speed. It is worth noting that at the present time the physics of such consistent media is poorly understood, and there are no systematic data in the field of debrisflow, soil mechanics and engineering geology on the dynamics of highly filled suspensions, including ground ones. There are separate separate studies in the field of mining and fuel industry due to the fact that the water-coal suspensions are a promising source of fuel.

For landslides-flows formed on the rock dumps of coal mining enterprises, characterized by features inherent in all landslides of the glacier type. According to the mechanism of formation of these landslides can be attributed to landslides extrusion, shear or liquefaction. The movement of landslide masses occurs at low speeds (up to $2-4 \mathrm{~m} / \mathrm{s}$ ). In the body of a 
moving landslide-flow there is a significant velocity gradient in the depth of the flow. In the bottom parts due to the friction force on the sliding surface, there is a significant decrease in the speed of movement, which leads to a mutual parallel displacement of individual layers and conglomerates. The upper layers move much faster [3]. When capturing a landslide-flow in the area of origin of any objects, they move for some time on its surface, reaching the front edge ("head of the landslide") where they are buried, objects that are directly in the transit zone of the landslide-flow, immediately find themselves buried landslide masses (Fig. 2).

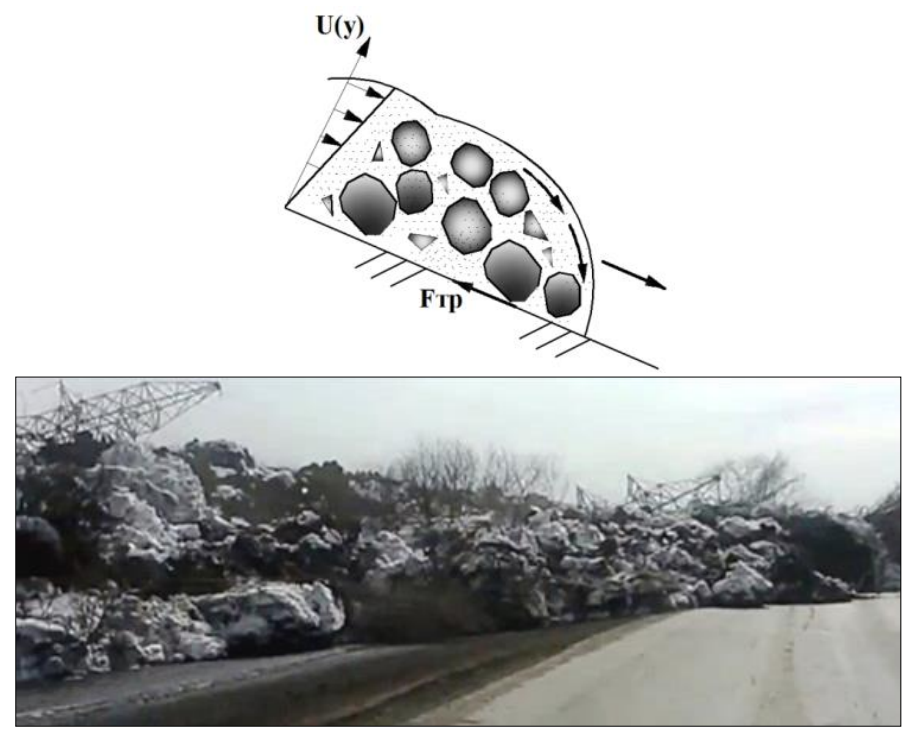

Fig. 2 a) Scheme of movement of a landslide flow. b) Movement of a landslide-stream from the Zarechny dam, The Kemerovo Region, Photo: http://www.like-a.ru/?p=21205\#.

The relative humidity of landslide masses in landslides-flows can reach 20-30\%. During the movement of the landslide, most of the water inside the landslide masses, unlike the debris flow, is in a connected state. After the stop of the landslide-flow, intensive separation of the suspension, characteristic for mud flows, is not observed. The decay of water-coal suspensions inside landslide masses of rock dumps of coal-mining enterprises takes place mainly by radiation.

In the zone of accumulation of the landslide-flow, it gradually slows down and decreases the depth of the stream. In theory, the movement and spreading of landslide masses occurs until the thickness of the flow reaches the thickness of the bottom layer. In this case, due to the friction force on the sliding surface with minimal slopes, the landslide-flow is completely stopped. In the case of the formation of landslides-flows of coal rock, this thickness is equal to the average conditional size of the stone. In practice, the complete stop of the landslide masses occurs much earlier than the depth of the bottom layer thickness, due to the increase in the viscosity of the outer layers of the landslide during their natural radiation drying.

\section{Factors of activation of landslides-flows in rock dumps}

Among the factors of activation of landslides-flows on the rock dumps of coal mining enterprises should be identified: anthropogenic, geological, hydrological, hydrogeological and meteorological factors.

Most often, the formation of large landslides-flows are caused by anthropogenic factors associated with errors in the design and operation of rock dumps. 
Anthropogenic factor enhancing include:

1. Errors in the planned location of rock dumps:

a) storage of rock dumps on slopes (upland dumps) without ensuring the stability of the dumps themselves and the underlying rocks that are the basis for the dump;

b) placement of rock dumps in negative forms of relief (ravines, valleys, decays, etc.) used to increase storage volumes. These elements of the relief have their own catchment and are often channels of permanent or temporary streams, which leads to an increase in the moisture content of man-made soils and the danger of destruction of slopes of dumps by filtration, as well as temporary flows.

2. Violation of warehousing technology. Warehousing in the form of burts (open area storehouses of rock storage) without the providing of storage technology: compaction and compliance with the stability of slopes. Unlike waste heaps, the burts are distinguished by more gentle slopes and significant horizontal projections. This causes a more intense hydration of rocks stored in the burt during the rains or snowmelt. Active operation of rock dumps during the activation of dangerous slope exogenous processes can significantly increase the load on the unstable base of the dump, causing the development of landslides of shear and extrusion.

3. Lack of wastewater collection disposal. The absence of drainage ditches, including upland ditches, as well as the lack of measures for clearing the storage areas from snow, also lead to an increase in the humidity of man-made soils of rock dumps, as a result of which a considerable volume of snow is buried.

4. Increase in surface runoff within man-made landscapes as a result of:

a) reduction of transpiration due to lack of vegetation cover;

b) due to the significant energy of the relief;

c) intensive snowmelt. For coal-mining enterprises, there are significant volumes of solid emissions of coal dust into the atmosphere. Due to the finely dispersed composition (from $300 \mu \mathrm{m}$ to $50 \mu \mathrm{m}$ ), coal dust is spread over considerable distances: sedimentation and deposition of coal dust are recorded within a radius of $10-15 \mathrm{~km}$. The finely dispersed composition and the negative charge of coal dust particles contribute to their active accumulation on various surfaces, including the surface of the snow cover during the winter period, and also prevents its deflation after interaction with the surfaces. In turn, the snow cover contaminated with coal dust significantly reduces its albedo, which leads to intensive snowmelt in the spring. The situation is aggravated by the fact that coals and carbonaceous overburden rocks at subzero temperatures have increased brittleness, which invariably leads to an increase in the formation of coal dust during loading and unloading operations and transportation of coals, as well as carbon-containing overburden. Near the coal-mining enterprises in the period of spring snowmelt, there are more intense floods and formation of temporary perched ground water than in areas free from contamination by coal dust. The increased humidification of soils of man-made landscapes activates the development of dangerous slope exogenous processes on their territory.

Geological factors include the placement of rock dumps on weak grounds, subject to denudation, erosion, liquefaction, etc., as well as the lithological composition and physical and mechanical characteristics of the stored overburden rocks.

Hydrological and hydrogeological factors of activation include the activity of permanent and temporary watercourses in the zone of disposal of waste dumps, as well as the activity of temporary non-slope slope flows and filtration flows on slopes, at the base and in the body of embankments of rock dumps.

Meteorological factor of activation of dangerous slope exogenous processes on rock dumps of coal-mining enterprises are phenomena that increase the relative humidity and reduce the physical and mechanical characteristics of man-made soils of rock heaps: precipitation and alternating air temperatures. 


\section{Conclusions}

Technogenic soils of rocky dumps of coal-mining enterprises are characterized by a decrease in the total number of rigid structural bonds and an increased content of fine dust particles, which contributes to their active involvement in dangerous slope exogenous processes of gravitational, water-gravity and fluvial nature (landslides, landslides, mudflows, etc.). The most dangerous are the landslides-flows, which are characterized by large volumes, emission distances and destructive force. The formation of large landslides-streams at coal mining enterprises is associated with the formation of water-coal suspensions as a result of waterlogging of man-made soils of rock dumps. Such suspensions are characterized by saturated consistency (up to $70 \%$ ) and pseudoplasticity - the property of reducing viscosity with increasing speed. The movement of landslide masses occurs at low speeds (up to 2-4 $\mathrm{m} / \mathrm{s}$ ) and has a significant velocity gradient in the depth of the flow. Among the factors of activation of landslides-flows on the rock dumps of coal mining enterprises should be identified: anthropogenic, geological, hydrological, hydrogeological and meteorological factors.

\section{Reference}

1. S.Yu. Kolomoets, Modern ecological problems of small rivers of the Kemerovo region. In the book: agricultural science-agriculture collection of articles in 3 books (Altai state agrarian University, 2016)

2. URL : http://wiki.gr-tech.ru/index.php?title=Tragedia_in_Aberfane

3. W. Wei, Recent Advances in Modeling Landslides and Debris Flows (Springer, 2016) 